\title{
COVID-19. The pandemic and the children
}

Looking at the history of humankind, this is not the first pandemic and it will not be the last. It started more than 7 months ago and we do not know when it will end. The causative agent was rapidly discovered. Diagnostic methods previously used for other viral diseases were adapted, and COVID-19 can now be diagnosed with a high level of sensitivity and specificity. No special studies were required to admit its high infectivity and spreading power. Many studies are ongoing, but there is still no available vaccine or effective treatment in place, only support therapy. The main conclusion so far is that the most effective measure is to prevent COVID-19 transmission through confinement: a measure that is vastly easier indicated than implemented and sustained over time.

Once the community spread of COVID-19 started, the response capacity of health systems worldwide to care for infected adults, especially those requiring critical care, was overstretched.

COVID-19 also affects children. The incidence of symptomatic infection is low $(1.7 \%)$. Most children with severe or critical involvement are those younger than 1 year and those with comorbidities; the fatality rate is very low compared to that of adults. In recent months, several cases have presented with an apparently post-infectious multisystem inflammatory syndrome, which frequently requires critical care.

In spite of the low fatality rate in children and adolescents, their safety is compromised by the so-called side effects of the pandemic, including the measures taken to reduce its spreading. Confinement recommendations and the constant dissemination of the growing number of infected and dead people in the mass media instill fear, but fail to offer an option to the families who are not able to comply with the requirements.

Just to make a quick enumeration: confinement; a lack of sunlight, fresh air, recreational spaces in contact with nature; no possibility of playing games and sports with their peers; loss of school and other learning and socialization spaces; a lack of physical contact with family and friends; higher risks for violence and abuse; and living in a "faceless" society undoubtedly have an impact on children's growth and development.

All these situations are even worse for children and adolescents living in poverty, in over- crowding conditions (4\% of all households in Argentina), in poor health conditions, with a lack of drinkable water (1 200000 households), and who cannot even afford their daily sustenance. Different global projections suggest that more than 1000000 preventable pediatric deaths may occur worldwide due to the lack of access to food and the interruption of essential health care services resulting from the pandemic. ${ }^{1,2}$

Job losses or the impossibility of performing informal work is another stressing experience for the family in addition to the difficulty of accessing an adequate nutrition. Before the beginning of the pandemic in Argentina, $53 \%$ of children and adolescents (7 000000 -a convincing absolute number) were living in poverty in 2019, and $16.3 \%$ (1 857 207) in extreme poverty or destitution. ${ }^{3} \mathrm{~A}$ study conducted by UNICEF ARGENTINA about the effects of COVID-19 estimated that the number of poor children in 2020 will increase to 7700000 , with 400000 more children living in extreme poverty. ${ }^{4}$

In the midst of all this, to reduce the risk for transmission and in the hope of preventing health systems from becoming overstretched, means of public transport were dramatically reduced, scheduled appointments were canceled, both well-child visits and follow-up visits for chronic conditions, "non-urgent" surgeries were called off, and attendance to immunization centers was reduced.

All of this results in a breakdown in the health system's power to monitor growth and development, provide preventive care, and a timely diagnosis and management of acute and chronic conditions, as well as treatment and support to children with different disabilities.

In a previous article (Bronchiolitis in the year of COVID-19), we anticipated that the incidence of seasonal respiratory diseases would probably be reduced due to the discontinuation of school, population confinement measures, and the introduction of good hygiene practices by the general population. ${ }^{5}$ This appears to be occurring not only in the pediatric population. But the circumstance described above is still a reason for concern: how will children with acute conditions or acute exacerbations of a chronic disease be able to receive care? Deaths and consequences among children with diseases not related to COVID-19 who sought care in a delayed manner due to 
their parents' fear of contagion are already being reported. ${ }^{6}$

An accompanying phenomenon is that the pediatric emergency departments of different countries have started to note a remarkable reduction in visits. ${ }^{7}$ This is also the case in our country. In two children's hospitals located in the Autonomous City of Buenos Aires, emergency visits in May decreased by $84 \%$ and $77 \%$ in relation to the same month in $2019 .{ }^{8}$ In one of these hospitals, in June, 11000 fewer children were seen in emergency and first-time visits compared to previous years. June is usually the peak month for visits due to an increase in seasonal respiratory diseases.

Is such remarkable reduction exclusively the result of a decrease in seasonal respiratory disease cases? What about other diseases? Will children develop disease complications due to a delayed consultation? In our setting, we should also consider the fear of contagion, the lack of available public transport, the change in health center care routines, and, above all, the absence of strategies designed for children, including credible information about the risks of not consulting or delaying office visits and immunizations.

The executive summary of the United Nations' document about the impact of COVID-19 on children is the best synthesis:

"Children are not the face of this pandemic. But they risk being among its biggest victims...the crisis is having a profound effect on their well-being. All children, of all ages, and in all countries, are being affected, in particular by the socio-economic impacts and, in some cases, by mitigation measures that may inadvertently do more harm than good. This is a universal crisis and, for some children, the impact will be lifelong. Moreover, the harmful effects of this pandemic will not be distributed equally. They are expected to be most damaging for children in the poorest countries, and in the poorest neighborhoods, and for those in already disadvantaged or vulnerable situations." ${ }^{\prime 9}$
We are aware that we are in the midst of an unprecedented crisis. Its actual impact will be evidenced much later, but its consequences are already taking place, and children are the most vulnerable population. Children's health and well-being should be the focus of recovery plans. But the problem is that the agenda should be centered on children and those plans should have been established "yesterday."

M. Susana Rodríguez, M.D.

Hospital de Pediatría "Prof. Dr. Juan P. Garrahan"

http:/ / dx.doi.org/10.5546/ aap.2020.eng.302

To cite: Rodríguez MS. COVID-19. The pandemic and the children Arch Argent Pediatr 2020;118(5):302-303.

\section{REFERENCES}

1. The WHO-UNICEF-Lancet Commissioners. After COVID-19, a future for the world's children? Lancet. Published online July $2^{\text {nd }}, 2020$.

2. Roberton T, Carter ED, Chou VB, Stegmuller A, et al. Early estimates of the indirect effects of the COVID-19 pandemic on maternal and child mortality in low-income and middleincome countries: a modelling study. Lancet Glob Health. 2020;8:901-8.

3. Argentina. Instituto Nacional de Estadísticas y Censos Incidencia de la pobreza y la indigencia en 31 aglomerados urbanos. Segundo semestre de 2019. Condiciones de vida. Vol. $4 \mathrm{n}^{\circ}$ 4. Informes Técnicos. 2019;3(59).

4. UNICEF Argentina. La pobreza y la desigualdad de niñas, niños y adolescentes en la Argentina. Efectos delCOVID-19. Abril 2020. [Accessed on: June 13 ${ }^{\text {th }}, 2020$ ]. Available at: https: / / www.unicef.org/argentina/informes / pobrezadesigualdad-infantil-covid19

5. Rodríguez MS. La bronquiolitis en el año del COVID-19. Arch Argent Pediatr. 2020;118(3):222-3.

6. Lazzerini M, Barbi E, Apicella A, Marchetti F, et al. Delayed access or provision of care in Italy resulting from fear of COVID-19. Lancet Child Adolesc Health. 2020;4(5):e10-1.

7. Isba R, Edge R, Jenner R, Broughton E, et al. Where have all the children gone? Decreases in paediatric emergency department attendances at the start of the COVID-19 pandemic of 2020. Arch Dis Child. 2020;105(7):704.

8. Ferrero F, Ossorio MF, Torres FA, Debaisi G. Impact of the COVID-19 pandemic in the paediatric emergency department attendances in Argentina. Arch Dis Child. Published online Jun 18, 2020.

9. United Nations. Policy Brief: The Impact of COVID-19 on children. 15 abril 2020. [Accessed on: June 13 $3^{\text {th }}, 2020$ ]. Available at: https://unsdg.un.org/sites/default/ files/2020-04/160420_Covid_Children_Policy_Brief.pdf 